\title{
Leishmania (Leishmania) hertigi in a porcupine (Coendou sp.) found in Brasília, Federal District, Brazil
}

\author{
Leishmania (Leishmania) hertigi em porco-espinho (Coendou sp.) encontrado em Brasília, \\ Distrito Federal, Brasil \\ Denise Amaro da Silva ${ }^{1 *}$; Maria de Fatima Madeira² ${ }^{2}$ Carlos José Lima Barbosa Filho ${ }^{1}$; \\ Edvar Yuri Paheco Schubach ${ }^{1}$; Juliana Helena da Silva Barros ${ }^{2}$; Fabiano Borges Figueiredo ${ }^{1}$
}

${ }^{1}$ Laboratório de Pesquisa Clínica em Dermatozoonoses em Animais Domésticos, Instituto de Pesquisa Clínica Evandro Chagas - IPEC, Fundação Oswaldo Cruz - FIOCRUZ, Rio de Janeiro, RJ, Brasil

${ }^{2}$ Laboratório de Vigilância em Leishmanioses, Instituto de Pesquisa Clínica Evandro Chagas - IPEC, Fundaçăo Oswaldo Cruz - FIOCRUZ, Rio de Janeiro, RJ, Brasil

Received August 8, 2012

Accepted January 17, 2013

\begin{abstract}
Studies report the occurrence of Leishmania (Leishmania) hertigi in northern states of Brazil. In the present investigation, we describe the isolation of $L$. (L.) hertigi from a porcupine (Coendou sp.) found in Brasília, Federal District, center-west region of Brazil. During a study on canine visceral leishmaniasis conducted in the city of Brasília, Federal District, a porcupine was found dead on a public road. The animal was identified and fragments of intact skin and spleen were collected for isolation of parasite in the culture. This report of the occurrence of $L$. hertigi in another part of Brazil may help establish the distribution of this parasite in the country. Further studies are needed to better understand the role of $L$. hertigi in the pathology and pathogenesis of leishmaniasis and its survival in mammals and possible vectors.
\end{abstract}

Keywords: Leishmania (Leishmania) hertigi, porcupine, Coendou.

\section{Resumo}

Alguns estudos relatam o encontro de Leishmania (Leishmania) hertigi em estados da regiấo Norte do Brasil. Na presente investigação, os autores descrevem o isolamento de Leishmania (Leishmania) hertigi em um porco-espinho (Coendou sp.) encontrado em Brasília, Distrito Federal, regiáo Centro-oeste do Brasil. Durante um estudo de leishmaniose visceral canina conduzido na cidade de Brasília, Distrito Federal, um porco-espinho foi encontrado morto em via pública. $\mathrm{O}$ animal foi identificado e fragmentos de pele íntegra e baço foram coletados para isolamento do parasito em cultura. Esse relato da ocorrência de L. hertigi em outra região do Brasil pode contribuir para evidenciar a distribuição desse parasita no país. Vale ressaltar a necessidade de estudos para compreensão do papel L. hertigi na patologia e patogênese da leishmaniose e a sua sobrevivência em mamíferos e possíveis vetores.

Palavras-chave: Leishmania (Leishmania) hertigi, porco-espinho, Coendou.

\footnotetext{
${ }^{*}$ Corresponding author: Denise Amaro da Silva

Laboratório de Pesquisa Clínica em Dermatozoonoses em Animais Domésticos,

Instituto de Pesquisa Clínica Evandro Chagas - IPEC,

Fundação Oswaldo Cruz - FIOCRUZ, Rio de Janeiro, RJ, Brasil

e-mail: denise.silva@ipec.fiocruz.br
} 
Leishmania (Leishmania) hertigi is a natural parasite of the tropical porcupine (Coendou rothschildi), which was described for the first time in Panama. This specific new name was suggested due to the apparent host specificity of this parasite and the peculiar morphology of the amastigote forms that differ from those of other Leishmania species (HERRER, 1971).

In Brazil, $L$. hertigi has been associated with natural infection of Coendou prehensilis prehensilis in the state of Piauí (DEANE et al., 1974). On that occasion, the authors detected scanty large amastigotes in spleen and liver smears. In this host, infection is generally asymptomatic and only small numbers of amastigotes are found in the dermis and viscera (LAINSON, 2010).

This parasite was called Leishmania hertigi deanei (LAINSON; SHAW, 1977) based on morphology, biochemistry and other peculiarities, and was later renamed Leishmania Leishmania deanei (LAINSON; SHAW, 1977) because the measurements and other morphological characteristics of the parasite were exactly the same as those reported by Deane et al.(1974) for the amastigote forms found in the porcupine from Piauí, and there is no doubt that they were dealing with the same parasite.

The classification of this species was based on morphological (HERRER, 1971), biochemical (CHANCE et al., 1974; GARDENER et al., 1974) and biological characteristics (LAINSON; SHAW, 1974). Later, Leishmania hertigi was assigned to a complex comprising two species: Leishmania hertigi and Leishmania deanei (LAINSON; SHAW, 1977). Subsequent molecular data suggested that $L$. hertigi may be more closely related to the genus Endotrypanum than to the genus Leishmania (NOYES et al., 1997). In the 2005 classification, both Leishmania hertigi and Leishmania deanei were included under the category "Leishmania-like parasites of uncertain taxonomic position” (LAINSON; SHAW, 2005).

The insect vector of $L$. hertigi is still unknown (NOYES et al., 1997). However, considering the habit of the vertebrate hosts, one may speculate that these animals live close to the vectors that can be found in hollow trees.

According to Lainson (2010), despite extensive investigation no other mammalian host was found to be naturally infected with L. hertigi. This parasite does not infect humans and only transient infection has been observed in hamsters and mice experimentally infected with the parasite.

During a study on canine visceral leishmaniasis conducted in the city of Brasília, Federal District, a porcupine was found dead on a public road and was brought to our research team. The animal was identified only as Coendou sp. based on the Brazilian rodent guide (BONVICINO et al., 2008) and showed typical run over injuries.

Fragments of intact skin and spleen were collected for isolation of Leishmania sp. The tissue fragments were stored in sterile saline containing antibiotics and antifungal agents and were processed according to Madeira et al. (2006). After 15 days of culture, promastigote forms were isolated only from cultured skin fragments. The isolate was inoculated $\left(1 \times 10^{6} / 0.1 \mathrm{~mL}\right)$ into the paws of two hamsters (Mesocricetus auratus) and the animals were monitored for 5 months.

Etiological identification of the isolate was done by nested PCR and sequencing. Genomic DNA was extracted with the commercial kit DNAzol reagent (Invitrogen, USA) according to manufacturer instructions.
PCR was performed as described by Smith et al. (2008) using primers that amplify a partial sequence of the 18S rRNA gene of Leishmania. The external primers TRY927F (GAAACAAGAAACACGGGAG) and TRY927R (CTACTGGGCAGCTTGGA) were used in the first reaction, and the internal primers SSU561F (TGGGATAACAAAGGAGCA) and SSU561R (CTGAGACTGTAACCTCAAAGC) were used in the second reaction.

The PCR products were separated by electrophoresis on $1.5 \%$ agarose gel stained with ethidium bromide and analyzed with the L-PIX HE image analyzer (Loccus Biotechnologia ${ }^{\oplus}$, São Paulo, Brazil).

After PCR, the amplified product obtained in the second round with cultured forms was purified using the QIAquick Purification Kit (Qiagen, USA) following the manufacturer's instructions and the nucleotide sequences were determined with an automatic sequencer (3730 DNA Analyzer, Applied Biosystems). The sequence obtained was initially analyzed by the Blast program (http://blast. ncbi.nlm.nih.gov/Blast.cg) and the sequencing result was processed using the software MEGA version 4.19 and the neighbor joining (NJ) method that was used to construct the phylogenetic tree. All nucleotide sequences obtained in this study were compared using the program ClustalX10 with sequence from Leishmania hertigi retrieved from GenBank (GenBank Accession no. U59492.5) and others sequences of genus Leishmania also available in GenBank.

The inoculated animals developed no skin lesions during the observation period. However, promastigote forms could be isolated from the site of inoculation after 2 and 5 months, whereas cultures of specimens obtained from other sites such as skin, bone marrow, blood, spleen and liver were negative.

PCR resulted in the amplification of a product of about $900 \mathrm{bp}$ in the first reaction and of $700 \mathrm{bp}$ in the second reaction. Phylogenetic analysis based on the partial sequence of the $18 \mathrm{~S}$ rDNA using the Blast program showed that the strain isolated was similar to the Leishmania hertigi sequence deposited in GenBank under the accession number U59492.5 (99\% identity, query coverage of $100 \%$, and e-value of 00.0) (Figure 1). Both samples were grouped in a single clade (bootstrap 99\%). The sequence obtained in this study was deposited in GenBank under the accession number JQ822114.

Reports on the geographic distribution of $L$. hertigi are limited to Neotropical regions, mainly Panama and Costa Rica (LAINSON, 2010). In Brazil, this species was described only in the states of Pará and Ceará (DEANE et al., 1974). This is the first report of this species in the city of Brasília, center-west region of Brazil.

The spread of infectious agents, especially those of the genus Leishmania, is a known fact. The expansion of leishmaniasis in Brazil has been associated with the migration of humans and their animals (MARZOCHI; MARZOCHI, 1994). Within this context, the present study made two observations: first, the identification of a Leishmania species not described in the city of Brasília and, second, the finding of a wild animal runs over in an urban environment. These two situations alert to the need for environmental and epidemiological surveillance in this region.

Even as reported by other author (LAINSON, 2010), in this study, only transient infection was observed in hamsters experimentally infected with the parasite. 


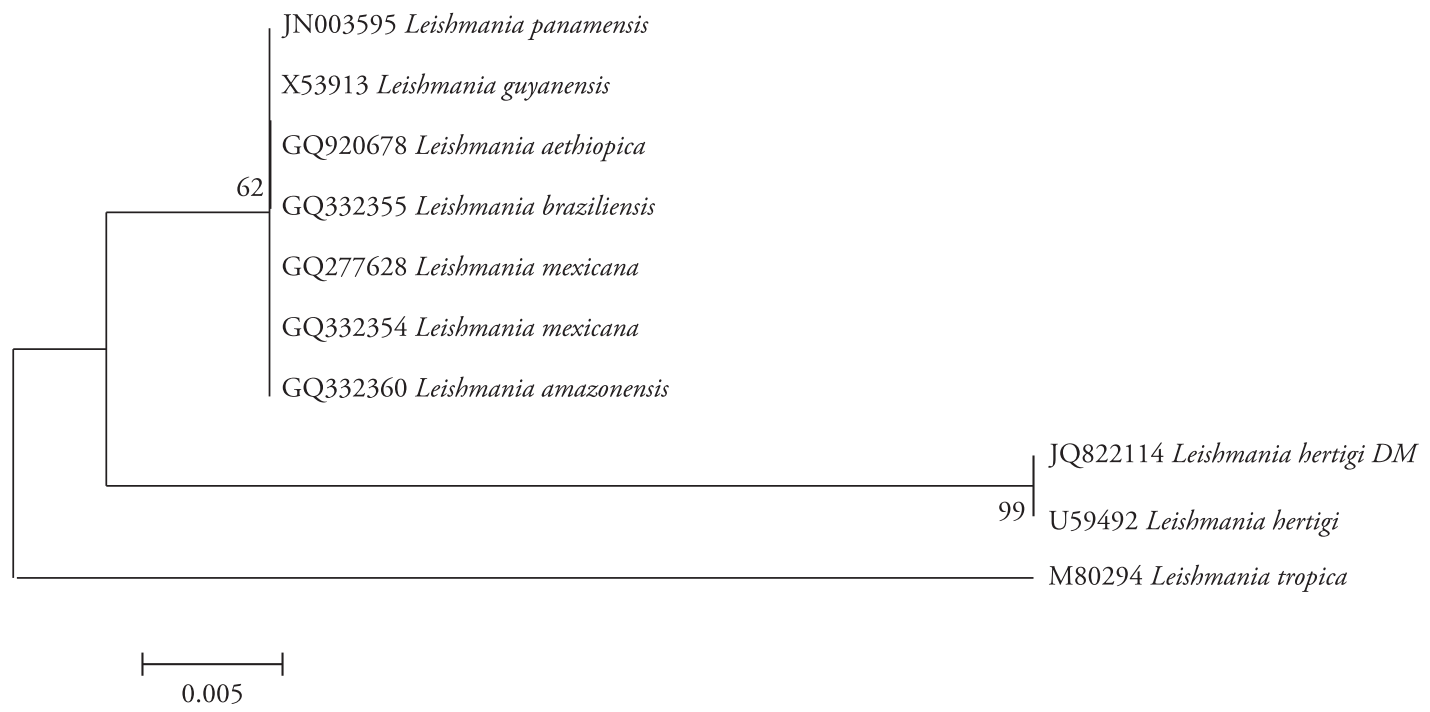

Figure 1. Neighbor-joining phylogenetic tree of the partial sequences of the 18S rRNA gene of Leishmania hertigi from Brasília, Federal District, Brazil and other parasites aligned with ClustalX program. The percentage of replicate trees, in which the associated taxa clustered together in the bootstrap test (1000 replicates), is shown next to the branches. Leishmania tropica was used as outgroup.

Phylogenetic analysis based on the partial sequences of the $18 \mathrm{~S}$ gene was sufficient to identify the isolate and contributed to a better understanding of the dissemination of L. hertigi in Brazil.

This report of the occurrence of $L$. hertigi in another part of Brazil may help establish the distribution of this parasite in the country. Further studies are needed to better understand the role of $L$. hertigi in the pathology and pathogenesis of leishmaniasis and its survival in mammals and possible vectors.

\section{Acknowledgements}

We thank the Genomic Platform - DNA Sequencing (PDTIS - Fiocruz) for supporting the sequencing of the samples and FAPERJ - Jovem Cientista do Nosso Estado.

\section{References}

Bonvicino CR, Oliveira JA, D’Andrea PS. Gênero Coendou, Ordem Rodentia, Familia Erethizontidae. In: Bonvicino CR, Oliveira JA, D'Andrea PS. Guia dos Roedores do Brasil: com chaves para gêneros baseadas em caracteres externos. Rio de Janeiro: Centro Pan-Americano de Febre Aftosa - OPAS/OMS; 2008. p. 87.

Chance ML, Peters W, Shchory L. Biochemical taxonomy of Leishmania. I. Observations on DNA. Ann Trop Med Parasitol 1974; 68(3): 307-316. PMid:4447389.

Deane LM, Silva JE, Figueiredo PZ. Leishmaniae in the viscera of porcupines from the state of Piauí, Brazil. Rev Inst Med Trop S Paulo 1974; 16(2): 68-69. PMid:4845452.

Gardener PJ, Chance ML, Peters W. Biochemical taxonomy of Leishmania. II: Electrophoretic variation of malate dehydrogenase. Ann Trop Med Parasitol 1974; 68(3): 317-325. PMid:4447390.

Herrer A. Leishmania hertigi sp. n., from the tropical porcupine, Coendou rothschildi Thomas. J Parasitol 1971; 57(3): 626-629. PMid:5090970. http://dx.doi.org/10.2307/3277928
Lainson R. The Neotropical Leishmania species: a brief historical review of their discovery, ecology and taxonomy. Rev Pan-Amaz Saude 2010; 1(2): 13-32. http://dx.doi.org/10.5123/S217662232010000200002

Lainson R, Shaw JJ. Las Leishmanias y la Leishmaniasis del nuevo mundo con particular referencia al Brasil. Bol Oficina Sanit Panam 1974; 76(2): 93-114. PMid:4274580.

Lainson R, Shaw JJ. Leishmanias of neotropical porcupines: Leishmania hertigi deanei nov. subsp. Acta Amaz 1977; 7(1): 51-57.

Lainson R, Shaw JJ. New World Leishmaniasis. In: Cox FEG, Wakelin D, Gillespie SH, Despommier DD. Topley \& Wilson's Microbiology and Microbial Infections: parasitology. 10th ed. London: Hodder Arnold ASM Press; 2005.

Madeira MF, De O Schubach A, Schubach TM, Pereira SA, Figueiredo FB, Baptista C, et al. Post mortem parasitological evaluation of dogs seroreactive for Leishmania from Rio de Janeiro, Brazil. Vet Parasitol 2006; 138(3-4): 366-370. PMid:16520002. http://dx.doi. org/10.1016/j.vetpar.2006.01.059

Marzochi MC, Marzochi KB. Tegumentary and visceral leishmaniases in Brazil - emerging anthropozoonosis and possibilities for their control. Cad Saúde Públ 1994; 10 (S2): 359-375. PMid:15042226. http://dx.doi. org/10.1590/S0102-311X1994000800014

Noyes HA, Arana BA, Chance ML, Maingon R. The Leishmania hertigi (Kinetoplastida; Trypanosomatidae) complex and the lizard Leishmania: their classification and evidence for a neotropical origin of the Leishmania-Endotrypanum clade. J Eukaryot Microbiol 1997; 44(5): 511517. PMid:9304821. http://dx.doi.org/10.1111/j.1550-7408.1997. tb05732.x

Smith A, Clark P, Averis S, Lymbery AJ, Wayne AF, Morris KD, et al. Trypanosomes in a declining species of threatened Australian marsupial, the brush-tailed bettong Bettongia penicillata (Marsupialia: Potoroidae). Parasitology 2008; 135(11): 1329-1335. PMid:18752704. http://dx.doi. org/10.1017/S0031182008004824 